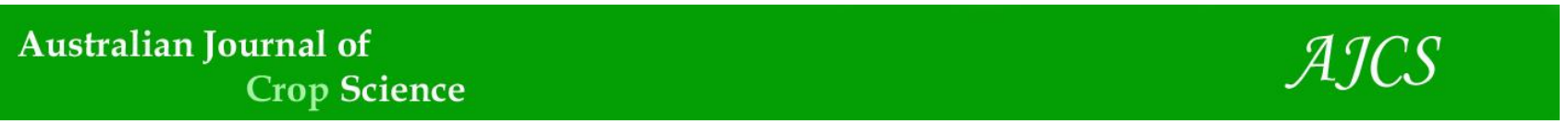

AJCS 14(08):1335-1341 (2020)

ISSN:1835-2707

doi: 10.21475/ajcs.20.14.08.p2629

\title{
Phosphorus (P) improves industrial tomato quality and yield in soil with high phosphorus content
}

\author{
Arthur Bernardes Cecílio Filho ${ }^{1 *}$, Bruno Trevizaneli ${ }^{2}$, Sergio Manuel Rugeles-Reyes ${ }^{3}$ \\ ${ }^{1}$ Department of Plant Production, Sao Paulo State University, Jaboticabal, Brazil \\ ${ }^{2}$ Predilecta Industry, Guaíra, Brazil \\ ${ }^{3}$ Department of Agricultural Sciences, National University of Colombia, Bogotá, Colombia
}

*Corresponding author: arthur.cecilio@unesp.br

Abstract

Soils under intensive and successive cropping with central pivot irrigation tend to present high nutrient contents, especially phosphorus $(\mathrm{P})$, which is a nutrient with a great impact on the yield and quality of agricultural products. Among the rotating crops, the application of high $\mathrm{P}$ rates is common in processing tomato, although not supported by research. This work evaluates the effect of phosphate fertilization $\left(0,200,400,600,800\right.$, and $\left.1000 \mathrm{~kg} \mathrm{ha}^{-1} \mathrm{P}_{2} \mathrm{O}_{5}\right)$ on the yield and quality of industrial tomato 'Heinz 9553 ' grown in a soil with high available $\mathrm{P}$ content $\left(145 \mathrm{mg} \mathrm{dm}^{-3}\right)$ resulting of an intensive vegetables cultivation, which have high demand by $\mathrm{P}$. The highest total $\left(127.4 \mathrm{t} \mathrm{ha}^{-1}\right)$ and commercial $\left(108.6 \mathrm{t} \mathrm{ha}^{-1}\right)$ yields were obtained with 413.9 and $384 \mathrm{~kg} \mathrm{ha}^{-1} \mathrm{P}_{2} \mathrm{O}_{5}$, respectively. The results showed that $\mathrm{pH}$ of tomato juice, the percentages of green, red, and commercial fruits were not influenced by the applied $P$ rates. However, nutrient delivery increased the soluble solids content up to $356 \mathrm{~kg} \mathrm{ha}^{-1} \mathrm{P}_{2} \mathrm{O}_{5}$, which is interesting for tomato processing. After harvesting the fruits, the available soil $\mathrm{P}$ content was increased with $\mathrm{P}$ supply to the plants. For improvement of commercial yield and soluble solids characteristics, the tomato crop shall be fertilised with P even though the soil has high P content.

Keywords: agribusiness; commercial fruits; phosphate fertilization; Solanum lycopersicum; soluble solids.

Abbreviations: $\mathrm{CF}_{-}$percentage of the total as commercial fruit; $\mathrm{CY}_{-}$commercial yield; $\mathrm{GF}_{-}$percentage of the total as green fruit; LPC_leaf phosphorus content; PS_ phosphorus soil content; RF_ percentage of the total as reed fruit; SS_ total soluble solids; TY_ total yield.

Introduction

Tomato (Solanum lycopersicum L.) is among the most consumed vegetables in the world, being a crop produced under a wide range of production systems (Marques et al., 2018). Tomato production in Brazil, including industry and fresh market, covers 64 thousand ha, totaling 4,373,047 t (IBGE, 2018). São Paulo State has a considerable participation in this agribusiness, being the second producer at national level, with 938 thousand $\mathrm{t}$ and an average productivity of $75 \mathrm{t} \mathrm{ha}^{-1}$ (IBGE, 2018).

Tomato fertilization represents $18 \%$ of the production cost (CEPEA, 2011), and adequate management of mineral nutrition is a determinant factor to reach high yield and profitability (Cecilio Filho et al., 2017). Phosphorus (P) stands out among the nutrients with the greatest impact on this crop. Although absorbed in small quantities by the tomato plant (Mueller et al., 2015), P is a strategic element because it is a constituent of nucleic acids and phospholipids. It is also important in photosynthesis, root development, and absorption of nutrients and water, further improving disease resistance (Dias et al., 2009; Zhu et al., 2017), which contributes greatly to tomato yield and quality. For adequate growth and development, the $\mathrm{P}$ content in the diagnostic leaf of tomato should be from 4 to $8 \mathrm{mg} \mathrm{kg}^{-1}$ (Trani and van Raij, 1997), or from 3 to $5 \mathrm{~g} \mathrm{~kg}^{-1}$, which is the value for herbaceous plants in general (Hawkesford et al., 2012).

The response of crops to phosphate fertilization depends on the species and the soil P availability (Wang and Li, 2004). Faria et al. (1999) mentioned that the probability of tomato responding to phosphate fertilization is minimal, when the $P$ content is equal to or greater than $15 \mathrm{mg} \mathrm{dm}^{-3}$. However, Coutinho et al. (2014) found a positive response in commercial fruit production with the rate of $150 \mathrm{~kg} \mathrm{ha}^{-1} \mathrm{P}_{2} \mathrm{O}_{5}$ in a soil with $23 \mathrm{mg} \mathrm{dm}^{-3} \mathrm{P}_{\text {(resin) }}$. Trani et al. (1997) and Barbosa et al. (2018) recommend phosphate fertilization for industrial tomato, when soil P levels are high (> $60 \mathrm{mg} \mathrm{dm}^{-3}$ ) and very high (> $\left.120 \mathrm{mg} \mathrm{dm}^{-3}\right)$, respectively.

In addition to the yield, tomato quality has gained interest among consumers and industry. Thus, fruit characteristics such as soluble solids content and fruit juice $\mathrm{pH}$ are important in the transformation processes of the raw material, and may be influenced by P fertilization (Liu et al., 2011; Coutinho et al., 2014). 
Due to the importance of this nutrient in the crop, tomato producers apply high $P$ rates, although these have not been recommended by research. The result of this action may be negative from the agronomic, environmental, and economic point of view. Nonetheless, the lack of scientific results explains the action of producers. The outdated official fertilization recommendation of tomato for industrial purposes has shown low efficiency of phosphate fertilization in tropical soils (Cecílio Filho et al., 2015). This is due to $P$ adsorption by iron and aluminum oxides under acidic conditions, which limits its availability to plants (Hopkins and Ellsworth, 2005; Cecílio Filho et al., 2015). São Paulo State is one of the main tomato producing regions of Brazil and the recommendation is $100 \mathrm{~kg} \mathrm{ha}^{-1} \mathrm{P}_{2} \mathrm{O}_{5}$, when the soil $\mathrm{P}$ content is greater than $60 \mathrm{mg} \mathrm{dm}^{-3}$ (Trani et al., 1997). The same nutrient amount is recommended, when soil $\mathrm{P}$ content is greater than $120 \mathrm{mg} \mathrm{dm}^{-3}$, according to Barbosa et al. (2018). However, much higher rates are frequently used (of up to $1200 \mathrm{~kg} \mathrm{ha}^{-1} \mathrm{P}_{2} \mathrm{O}_{5}$ ) aiming to maintain productivity (Marques et al., 2018).

Regarding fruit yield and quality, tomato responses to phosphate fertilization need to be better understood in the cultivation regions, due to the potential of $P$ to pollute and deplete oxygen from water sources, leading to eutrophication (Bolster and Sistani, 2009) and causing heavy metal accumulation in the soils (Jiao et al., 2012).

In view of the above, and considering that the majority of studies related to phosphate fertilization in tomato have been done on soils with low or medium P content, this study evaluates the tomato response to phosphorus rates when cultivated in an Oxisol with high content of this nutrient, considering industrial purposes.

\section{Results and Discussion}

\section{Yield}

Total and commercial yield were influenced by $P$ rates (Table 1), fitting the quadratic model for both variables (Fig 1). Total yield values ranged from 98.9 to $127.4 \mathrm{t} \mathrm{ha}^{-1}$, with the maximum value being estimated at $413.9 \mathrm{~kg} \mathrm{ha}^{-1} \mathrm{P}_{2} \mathrm{O}_{5}$, which represents an increase of $12 \%$ compared to the control. It should be noted that $1000 \mathrm{~kg} \mathrm{ha}{ }^{-1} \mathrm{P}_{2} \mathrm{O}_{5}$ resulted in the lowest value for this variable (98.9 $\mathrm{t} \mathrm{ha}^{-1}$ ). The highest commercial yield (108.6 kg ha ${ }^{-1}$ ) was reached by using of 384 $\mathrm{kg} \mathrm{ha}^{-1} \mathrm{P}_{2} \mathrm{O}_{5}$, while the lowest value corresponded to the rate of $1000 \mathrm{~kg} \mathrm{ha}^{-1} \mathrm{P}_{2} \mathrm{O}_{5}\left(86.6 \mathrm{t} \mathrm{ha}^{-1}\right)$.

Phosphorus extraction in tomato is low, when compared to cereals (Coutinho et al., 2014). However, due to the low efficiency of phosphate fertilization, high nutrient applications are common (Marques et al., 2018). In soils with $P$ levels greater than $60 \mathrm{mg} \mathrm{dm}^{-3}$, Trani et al. (1997) recommend $100 \mathrm{~kg} \mathrm{ha}^{-1} \mathrm{P}_{2} \mathrm{O}_{5}$ for industrial tomato. In the present study, the soil presented $145 \mathrm{mg} \mathrm{dm}^{-3}$, and the maximum values of total and commercial yield were obtained with rates $313 \%$ and $284 \%$ higher than the recommended, respectively. Nevertheless, according to the fitted equation, $100 \mathrm{~kg} \mathrm{ha}{ }^{-1} \mathrm{P}_{2} \mathrm{O}_{5}$ would be required to reach $95 \%$ of maximum commercial yield, which corroborates the recommendation of Trani et al. (1997). At rates above 413.9 and $384 \mathrm{~kg} \mathrm{ha}^{-1} \mathrm{P}_{2} \mathrm{O}_{5}$, total and commercial yield decreased by up to $22 \%$ and $26 \%$, respectively. The results suggest that even in soils with high $\mathrm{P}$ levels, the tomato cultivar 'Heinz
9553' responds positively to phosphate fertilization. In contrast, Zhang et al. (2007) reported P effect only when soil nutrient contents were low or medium.

Zhang et al. (2007) and Nowaki et al. (2017) did not observe effect of phosphorus supply on commercial yield in soils with high $\mathrm{P}$ levels. Coutinho et al. (2014) reported a positive response of $\mathrm{P}$ application (up to $290 \mathrm{~kg} \mathrm{ha}^{-1} \mathrm{P}_{2} \mathrm{O}_{5}$ ) to commercial yield in a soil with medium $P$ content $(23 \mathrm{mg} \mathrm{dm}$ $\left.{ }^{3} \mathrm{P}_{(\text {resin) }}\right)$. Liu et al. (2011) evaluated applications of 0 to 206 $\mathrm{kg} \mathrm{ha}{ }^{-1} \mathrm{P}_{2} \mathrm{O}_{5}$ in soil with $65 \mathrm{mg} \mathrm{kg}^{-1} \mathrm{P}_{(\text {Olsen) }}$, and found higher total yield at the highest rate.

The observed increases in yield in the present study can be attributed to phosphorus functions in plant metabolism, since the element is involved in the processes of photosynthesis, respiration, and cell division, also being a structural component of phospholipids, nucleic acids, and coenzymes (Fageria, 2009; Hawkesford et al., 2012). Dias et al. (2009) mentioned that phosphorus supply improves root development and increases the plant's ability to absorb water and other nutrients. In tomato, Melton and Dufault (1991) and Oke et al. (2005) reported that phosphate fertilization stimulates initial development and vegetative growth, while Conversa et al. (2013) mentioned that P can favor production components such as the number of flowers and fruits per plant and individual fruit weight, leading to higher yields.

In tomato, fruit color is an indicator of quality for in natura consumption and processing, since it is related to the presence of carotenoids, mainly lycopene and $\beta$-carotene (Oke et al., 2005). In this way, a higher proportion of red tomatoes is desirable for the industry. In the present study, the proportion of commercial (colored and red) fruits was not significantly influenced by the increase in phosphorus supply to the plants (Table 1 ). The average percentage of commercial fruits in relation to the total produced was $86.60 \%$, which is within the range of 5 to $15 \%$ of discard, verified in the region of Guaíra. Moreover, there were no significant adjustments for the percentages of green, red, and commercial fruit production in relation to the total produced.

A similar result was found by Conversa et al. (2013), who did not observe effect of phosphorus rates $(0,60$, and $120 \mathrm{~kg}$ ha ${ }^{1} \mathrm{P}_{2} \mathrm{O}_{5}$ ) on the number of commercial fruits per plant, during two consecutive years. Zhu et al. (2017) evaluated P applications in the color of 'Ridgerunner' tomato fruits, and found no significant effect. Thus, the results obtained suggest that the color of the fruit and the proportion of red fruits are parameters influenced predominantly by the tomato cultivar and not by $P$ fertilization, as mentioned by Adebooye et al. (2006) and Zhu et al. (2017).

\section{Juice quality}

The $\mathrm{pH}$ values of fruit juice were between 4.47 and 4.55 , but were not influenced by $P$ rates (Table 2 ). These values are close to 4.25. The acidity was considered as optimum for tomato processing according to Anthon et al. (2011). Similar results were obtained by Oke et al. (2005) and Coutinho et al. (2014) in 'H9478' and 'IPA-5' processing tomatoes, respectively. According to Garcia and Barret (2006), $\mathrm{pH}$ is a characteristic that influences the duration of the thermal processing of tomato; therefore, values lower than 4.6 are desirable to inhibit microbial growth during pulp processing. 
Table 1. Summary of variance analysis for total (TY) and commercial (CY) yields, and percentage of the total as green fruits (GF), red fruits (RF) and commercial fruits (CF) produced as function of phosphorus rates.

\begin{tabular}{|c|c|c|c|c|c|}
\hline Phosphorus & TY & $\mathrm{CY}$ & GF & RF & $\mathrm{CF}$ \\
\hline$\left(\mathrm{kg} \mathrm{ha}^{-1} \mathrm{P}_{2} \mathrm{O}_{5}\right)$ & \multicolumn{2}{|c|}{------- t ha ${ }^{-1}$--------- } & \multicolumn{3}{|c|}{ - } \\
\hline 0 & 113.42 & 97.61 & 14.0 & 60.9 & 85.8 \\
\hline 200 & 123.34 & 110.60 & 10.2 & 65.2 & 89.6 \\
\hline 400 & 125.00 & 108.30 & 12.5 & 63.1 & 87.0 \\
\hline 600 & 130.44 & 109.06 & 16.2 & 65.6 & 82.0 \\
\hline 800 & 109.96 & 93.18 & 14.1 & 64.1 & 84.8 \\
\hline 1000 & 100.38 & 90.40 & 11.3 & 73.1 & 90.4 \\
\hline CV (\%) & 5.83 & 9.31 & 54.8 & 20.8 & 6.7 \\
\hline Values of $\mathrm{F}$ & $10.67 * *$ & $3.45^{*}$ & $0.38^{\text {ns }}$ & $0.38^{\text {ns }}$ & $1.15^{\mathrm{ns}}$ \\
\hline
\end{tabular}

${ }^{(n s)}$ not significant by $\mathrm{F}$ test $(\mathrm{p}>0.05) ;{ }^{(*)}$ significant by $\mathrm{F}$ test $(\mathrm{p} \leq 0.05) ;{ }^{(* *)}$ significant by $\mathrm{F}$ test $(\mathrm{p} \leq 0.01)$.

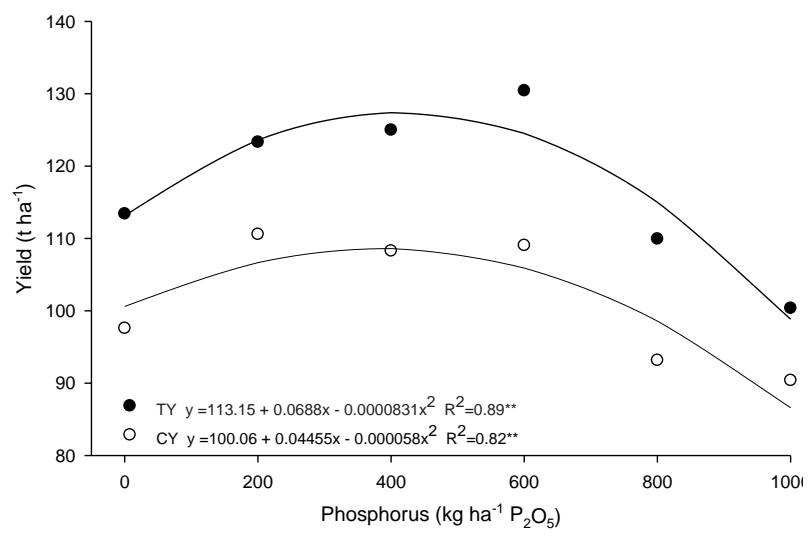

Fig 1. Total (TY) and commercial (CY) yields of tomato fruits for processing as function of phosphorus rates.

Table 2. Summary of variance analysis for $\mathrm{pH}$ and total soluble solids (SS) of tomato fruits, leaf phosphorus content (LPC), and P soil content (PS) as function of phosphorus rates.

\begin{tabular}{|c|c|c|c|c|}
\hline Phosphorus & \multirow{2}{*}{$\mathrm{pH}$} & SS & LPC & PS \\
\hline$\left(\mathrm{kg} \mathrm{ha}^{-1} \mathrm{P}_{2} \mathrm{O}_{5}\right)$ & & $\left({ }^{\circ}\right.$ Brix $)$ & $\left(\mathrm{g} \mathrm{kg}^{-1}\right)$ & $\left(\mathrm{mg} \mathrm{dm}^{-3}\right)$ \\
\hline 0 & 4.47 & 4.17 & 2.53 & 142 \\
\hline 200 & 4.55 & 4.32 & 2.65 & 423 \\
\hline 400 & 4.51 & 4.67 & 2.75 & 502 \\
\hline 600 & 4.48 & 4.32 & 2.74 & 722 \\
\hline 800 & 4.54 & 3.82 & 2.98 & 815 \\
\hline 1000 & 4.52 & 3.67 & 2.81 & 752 \\
\hline CV (\%) & 1.38 & 11.46 & 6.24 & 24.35 \\
\hline Valor de $\mathrm{F}$ & $0.72^{\mathrm{ns}}$ & $2.34^{\mathrm{ns}}$ & $3.17^{*}$ & $60.75^{* *}$ \\
\hline
\end{tabular}

${ }^{(n s)}$ not significant by $F$ test $(p>0.05) ;{ }^{(*)}$ significant by $F$ test $(p \leq 0.05) ;{ }^{(* *)}$ significant by $F$ test $(p \leq 0.01)$.

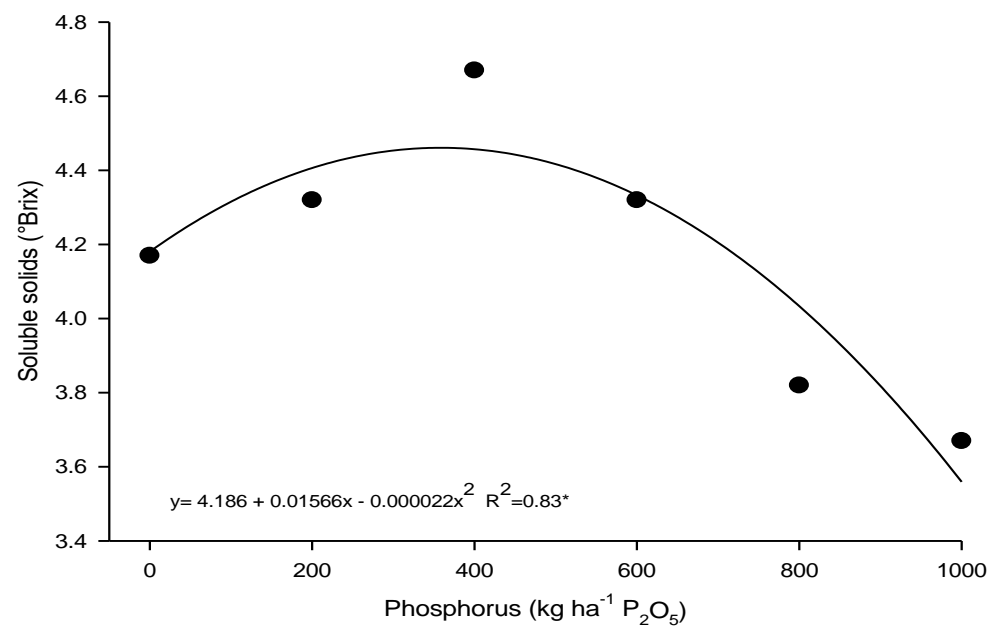

Fig 2. Soluble solids content of tomato for processing as function of phosphorus rates. 


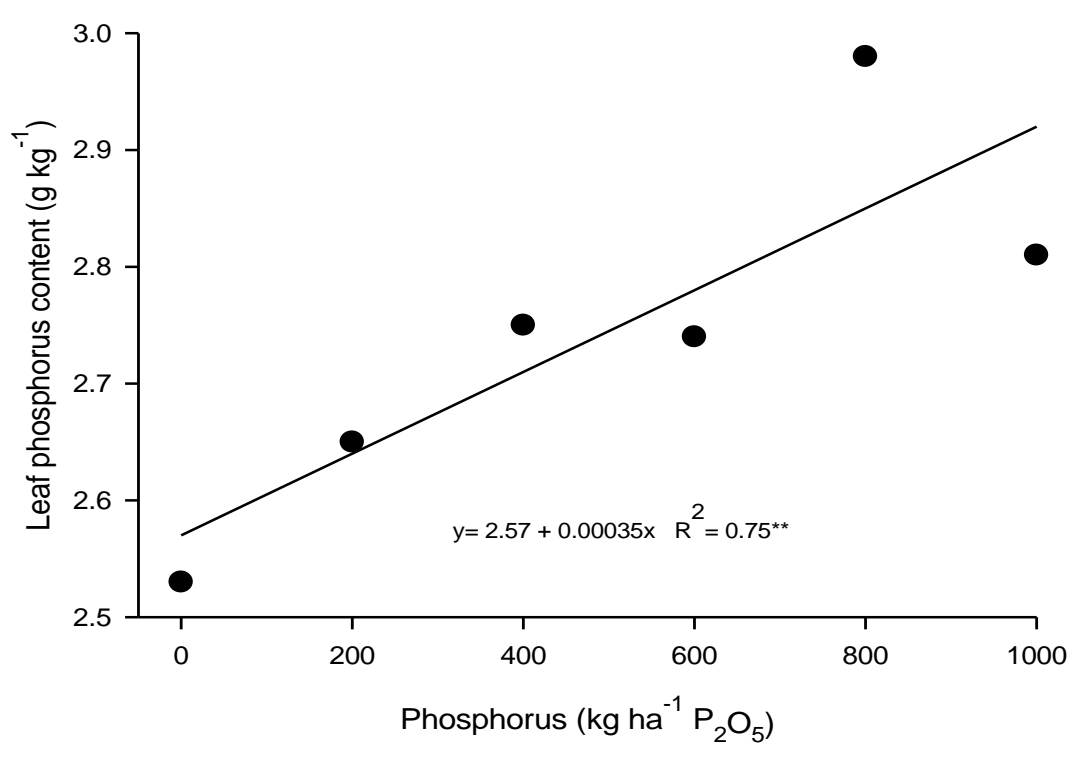

Fig 3. Leaf phosphorus content of tomato for processing as function of phosphorus rates.

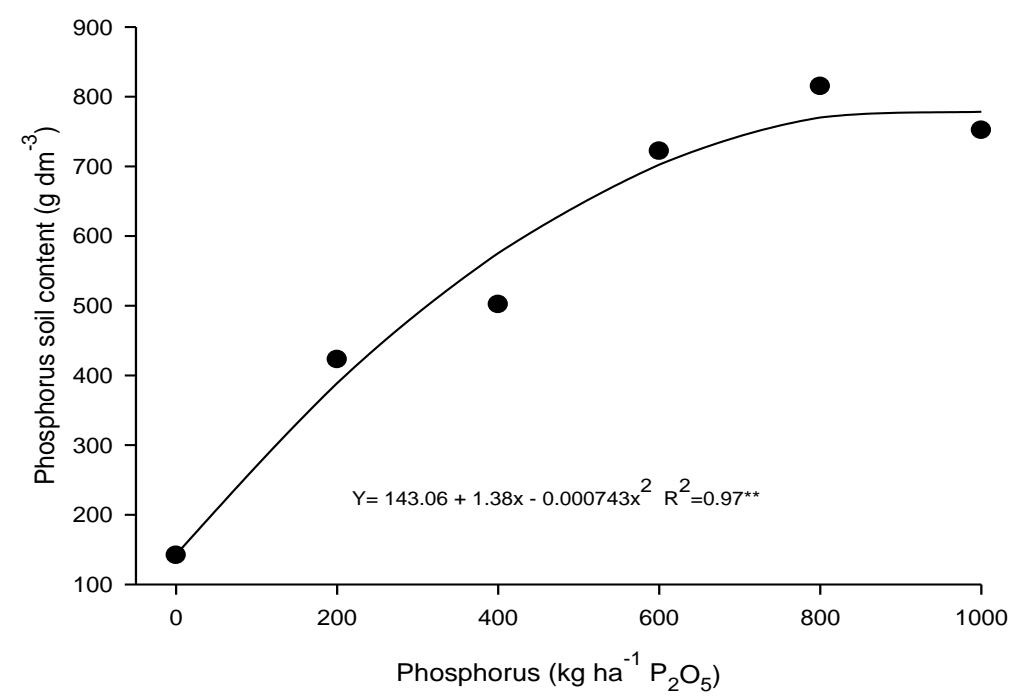

Fig 4. Phosphorus soil content of tomato for processing as function of phosphorus rates.

Soares and Rangel (2012) consider the soluble solids content as an important parameter for tomato processing, since the increase in a unit of ${ }^{\circ}$ Brix results in a $20 \%$ increase in industrial pulp yield. In the present study, without $P$ application, total soluble solids contents were below the range of 4 to $6^{\circ} \mathrm{Brix}$, even in soils with high $\mathrm{P}$ content. This value is considered ideal for the tomato industry (Soares and Rangel, 2012) (Fig 2). The maximum content was obtained with the estimated rate of $356 \mathrm{~kg} \mathrm{ha}^{-1} \mathrm{P}_{2} \mathrm{O}_{5}$, close to what is necessary to reach maximum commercial yield. Adebooye et al. (2006) reported similar results, finding that phosphorus application (121 kg ha ${ }^{-1} \mathrm{P}_{2} \mathrm{O}_{5}$ ) in a soil with $5.8 \mathrm{mg} \mathrm{kg}^{-1}$ (Bray 1) increased the soluble solids content in cultivars 'Roma VF' and 'Ibadan'. These results suggest that phosphorus applications in 'Heinz 9553' tomato favor the accumulation of soluble solids in the fruit, although cultivated in soil with high $\mathrm{P}$ content. It is possibly a consequence of the functions of the element in metabolism and sugar accumulation and transport within the plant (Prado, 2008). However, it is noted that the nutrient rate must meet a limit. In the present study, rates above $356 \mathrm{~kg} \mathrm{ha}^{-1} \mathrm{P}_{2} \mathrm{O}_{5}$ substantially reduced the soluble solids content to levels lower than that obtained without supplying $\mathrm{P}$ to tomato plants. The result corroborates the assertion of Zhang et al. (2010), that excessive rates of the nutrient could cause lower fruit quality.

\section{$P$ foliar and soil contents}

Phosphorus content in tomato leaves was influenced by $\mathrm{P}$ rates (Table 2, Fig 3). The highest leaf $P$ content $\left(2.92 \mathrm{~g} \mathrm{~kg}^{-1}\right)$ was estimated with $1000 \mathrm{~kg} \mathrm{ha}^{-1} \mathrm{P}_{2} \mathrm{O}_{5}$. The increase of leaf $P$ by higher nutrient rates is due to higher concentration of $P$ in the soil solution and higher uptake by the plant (Zhu et al., 2017). Coutinho et al. (2014) evaluated the application of four $\mathrm{P}$ rates $\left(0,150,300\right.$, and $\left.600 \mathrm{~kg} \mathrm{ha}^{-1} \mathrm{P}_{2} \mathrm{O}_{5}\right)$ in a soil with 
$23 \mathrm{mg} \mathrm{dm}{ }^{-3} P_{(\text {resin) }}$, also reporting that leaf phosphorus content increased with increasing $P$ rates.

Leaf $P$ contents were between 2.53 and $2.98 \mathrm{~g} \mathrm{~kg}^{-1}$ (Table 2), which could indicate nutrient deficiency according to Raij and Trani (1997), whereas they mentioned the range between 4 and $8 \mathrm{~g} \mathrm{~kg}^{-1} \mathrm{P}$ as suitable. However, no symptoms of deficiency were observed and the yields obtained were high, eliminating the possibility of the plant being Pdeficient. The low leaf $P$ contents may be due to dilution effects, since soil phosphorus content was high (145 mg dm ${ }^{3}$ ) even when $\mathrm{P}$ was not applied. Furthermore, in tomato, differences have been observed in the absorption of phosphorus as a consequence of abiotic and genetic (cultivar) factors (Marques et al., 2018).

Soil $\mathrm{P}$ content was influenced by $\mathrm{P}$ rates (Table 2 ), with quadratic adjustment. The maximum content was obtained with the estimated rate of $928.6 \mathrm{~kg} \mathrm{ha}^{-1} \mathrm{P}_{2} \mathrm{O}_{5}$ (Fig 4). The values ranged from $143 \mathrm{mg} \mathrm{dm}^{-3}$, in the control treatment (without $\mathrm{P}$ application), to $783 \mathrm{mg} \mathrm{dm}$ with the rate of $928.6 \mathrm{P}_{2} \mathrm{O}_{5}$, which represents a $447 \%$ increase. Cecílio Filho et al. (2013) also reported increases in soil $P$ content from 139 to $232 \mathrm{mg} \mathrm{dm}^{-3}$ with rates of 0 to $720 \mathrm{~kg} \mathrm{ha}^{-1} \mathrm{P}_{2} \mathrm{O}_{5}$ in soil with $93 \mathrm{mg} \mathrm{dm}^{-3} \mathrm{P}$. It is noteworthy that the $P$ levels found in the present study were above the value considered very high for horticultural crops, which is $120 \mathrm{mg} \mathrm{dm}^{-3}$ (Raij et al., 1996). Certainly, very high soil $P$ levels can have negative consequences for the environment, if care is not taken for soil conservation avoiding erosion and eutrophication of rivers and lakes (Tóth et al., 2014).

\section{Materials and Methods}

\section{Location and characterization of the experimental area}

The experiment was conducted from May 10 to September 24, 2011, in Sítio da Mata, Guaíra city, São Paulo State, at 20 12' 45.41" S, 48 26 57.71" W, and 528 meters of altitude.

The soil of the experimental area is classified as Eutroferric Red Latosol (Embrapa, 2013). Soil chemical characteristics in the $0-0.2 \mathrm{~m}$ layer prior to the installation of the experiment were: $\mathrm{pH}_{(\mathrm{CaC} \mid 2)} 6.1 ; \mathrm{O} . \mathrm{M} .=26 \mathrm{~g} \mathrm{dm}^{-3} ; \mathrm{P}_{(\text {resin) }}=145 \mathrm{mg} \mathrm{dm}^{-3}$; $4.3,60,19$, and $103.3 \mathrm{mmol}_{\mathrm{C}} \mathrm{dm}^{-3}$ of $\mathrm{K}, \mathrm{Ca}, \mathrm{Mg}$, and CEC, respectively; and $\mathrm{V}=81 \%$. In the experimental period, the mean temperature, mean maximum temperature, and mean minimum temperature were 28.3, 32.7, and $20.2{ }^{\circ} \mathrm{C}$, respectively. The $\mathrm{P}$ content is high according to Trani et al. (1997).

\section{Plant materials}

The tomato cultivar used was 'Heinz 9553', which is the most cultivated hybrid in Brazil for industrial purposes. Its characteristics include crop uniformity, concentration of maturity, good color of the fruit, high soluble solids content, good yield, and high total acidity (Soares and Rangel, 2012).

\section{Experimental design and treatments}

The treatments consisted of six phosphorus rates $(0,200$, $400,600,800$, and $\left.1000 \mathrm{~kg} \mathrm{ha}^{-1} \mathrm{P}_{2} \mathrm{O}_{5}\right)$ using triple superphosphate $\left(42 \% \mathrm{P}_{2} \mathrm{O}_{5}\right)$ as $\mathrm{P}$ source. The definitions of the phosphorus rates were based on the rate of 400 to 800 $\mathrm{kg} \mathrm{ha}{ }^{-1} \mathrm{P}_{2} \mathrm{O}_{5}$ used by industrial tomato producers in the region of Guaíra.

The experimental design was a randomized block design, with six treatments and four replicates. The experimental unit contained three 5-m long plant rows. The lateral rows of the experimental unit were considered as border plants, as well as the first two and last plants of the central row.

\section{Experiment installation and conduction}

Soil tillage consisted of plowing and harrowing. Liming was performed to raise the soil base saturation to $85 \%$ and the magnesium content to a minimum of $9 \mathrm{mmol}_{\mathrm{c}} \mathrm{dm}^{-3}$. Following the recommendations of Trani et al. (1997), planting fertilization was performed with $30 \mathrm{~kg} \mathrm{ha}^{-1} \mathrm{~N}, 60 \mathrm{~kg}$ $\mathrm{ha}^{-1} \mathrm{~K}_{2} \mathrm{O}$. Ammonium sulphate $(20 \% \mathrm{~N})$ and potassium chloride $\left(58 \% \mathrm{~K}_{2} \mathrm{O}\right)$ were used as source of nitrogen and potassium, respectively. Fertilizers were applied to the furrow, at about 0.15 to $0.2 \mathrm{~m}$ depth, before transplanting the seedlings.

Topdressing fertilization used $200 \mathrm{~kg} \mathrm{ha}^{-1}$ of ammonium nitrate, where half of the rate was applied at 14 days and the other half applied at 28 days. In addition to $200 \mathrm{~kg} \mathrm{ha}^{-1}$ potassium chloride, half of the rate was applied at 21 days and the other half applied at 45 days after transplanting the seedlings.

The tomato seedlings were transplanted on May 10, 2011, at five-leaf stage. A spacing of $0.25 \mathrm{~m}$ between plants and 1.25 $\mathrm{m}$ between rows was adopted, totaling $32,000 \mathrm{ha}^{-1}$ plants. Soon after the transplant, the seedlings were irrigated by central pivot, starting with a $10-\mathrm{mm}$ water depth. During the whole cycle, approximately $380 \mathrm{~mm}$ of water was used, which applied according to the needs of the plant, considering the data provided by the tensiometers installed in the area. Phytosanitary and weed control were carried out following the recommendations for the crop (Clemente and Boiteux, 2012).

The harvest was performed on September 24, 2011, at 137 days after transplanting. At the time of harvesting, at least $85 \%$ of the fruits were at harvest point in at least one of the treatments, meeting the industrial characteristics, such as soluble solids content, uniformity of maturation, and color.

\section{Evaluated characteristics}

Leaf phosphorus content (LPC): After the appearance of the first ripe fruit, leaf samples were collected to evaluate the nutritional status. Three fully developed leaves were removed per plant, in a total of 5 plants per experimental unit (Trani and Raij, 1997). The leaves were washed with tap water and deionized water. Afterwards, they were placed in identified paper bags and subjected to drying in an oven with forced air circulation at $65 \stackrel{\circ}{\circ}$ until constant mass. Then, each sample was ground in a Wiley mill. Leaf $P$ contents were determined according to the methodology proposed by Bataglia et al. (1983).

Total yield (TY) and commercial yield (CY): The harvested fruits were visually classified according to the color of the epidermis: red fruits (those with all the epidermis in red, at any intensity), colored fruits (those which had green, yellow, and red proportions in the epidermis), and green fruits (those with all the epidermis in green, at any intensity). Subsequently, the fruits were weighed. Total yield corresponded to the sum of the three classes of fruits, while 
commercial yield considered red and colored fruits, which are those used for industrial processing. The data obtained in TY enabled the estimation of the proportions of red (RF), green (GF), and commercial (CF) fruits.

Total soluble solids (SS) content and juice $\mathrm{pH}$ : Five commercial fruits were sent to the laboratory for quantification of soluble solids, obtained with a portable refractometer (Instrutherm ${ }^{\circledast}$ ). Afterwards, the fruits were ground, and the juice $\mathrm{pH}$ was measured with a digital $\mathrm{pH}$ meter.

Soil phosphorus content (PS): After the fruits were harvested, eight soil samples of the 0-0.2 m layer were collected per experimental unit in the planting furrow, being homogenized. Then, $250 \mathrm{~g}$ were collected for evaluation of $P$ content, according to the methodology of Raij et al. (2001).

\section{Statistical analysis}

According to the proposed design, the data were submitted to analysis of variance by the $F$ test $(\alpha \leq 0.05)$ and to regression analysis. When significant, we chose the equation with significance and higher coefficient of determination.

\section{Conclusions}

Even in soils with a very high phosphorus content, tomato responds positively to phosphate fertilization in yield and soluble solids content.

\section{References}

Adebooye OC, Deoye GO, Tijani-Eniola H (2006) Quality of fruits of three varieties of tomato (Licopersicum esculentum (L.) Mill) as affected by phosphorus rates. J Agron. 5: 396-400.

Anthon GE, Lestrange M, Barret DM (2011) Changes in pH, acids, sugars and other quality parameters during extended vine holding of ripe processing tomatoes. J Sci Food Agri. 91: 1175-1181.

Barbosa V, Trani PE, Passos FA, Vieira M (2018) Tomate para indústria. In.: Trani PE (ed). Hortaliças: recomendações de calagem e adubação para o Estado de São Paulo. Campinas, CATI. p. 80-83.

Bataglia OC, Furlani AM, Teixeira JP, Furlani PR, Gallo JR (1983) Métodos de análise química de plantas. Campinas: Instituto Agronômico, Brasil. p.48.

Bolster CH, Sistani KR (2009) Sorption of phosphorus from swine, dairy, and poultry manures. Commun Soil Sci Plant. 40: 1106-1123.

Cecílio-Filho AB, Filgueiras-Dutra A, Da Silva GS (2017) Phosphate and potassium fertilization for radish grown in a latosol with a high content of these nutrients. Rev Caatinga. 30: 412-419.

Cecílio-Filho AB, Pereira AL, Mendoza-Cortez JW, Barbosa JC (2015) Cauliflower and broccoli productivity as influenced by phosphorus fertilizer doses in a P-rich soil. Aust J Crop Sci. 9: 709-712.

Cecílio-Filho AB, Silva GS, Mendoza-Cortez JW (2013) Phosphorus fertilization of 'Futuyo' cabbages in phosphorus-rich Eutrustox soil. Chil J Agr Res. 73: 288-293. CEPEA (2011) Centro de Estudos Avançados em Economia Aplicada. Hortaliças: Gestão sustentável. Revista Hortifruti Brasil. 12-16.
Clemente FV, Boiteux L (2012) Produção de tomate para processamento industrial. Embrapa, Brasilia DF, Brazil. p.9.

Conversa G, Lazzizera C, Bonasia A, Elia A (2013) Yield and phosphorus uptake of a processing tomato crop grown at different phosphorus levels in a calcareous soil as affected by mycorrhizal inoculation under field conditions. Biol Fert Soils. 49: 691-703.

Coutinho EL, Valdeci OJ, Coutinho-Neto, Cardoso S (2014) Nutrición, producción y calidad de frutos de tomate para procesamiento en función de la fertilización con fósforo y potasio. Agrociencia Uruguay. 18: 40-46.

Dias TJ, Pereira WE, Cavalcante LF, Raposo RWC, Freire JL (2009) Desenvolvimento e qualidade nutricional de mudas de mangabeiras cultivadas em substrato contendo fibra de coco e adubação fosfatada. Rev Bras Frutic. 31: 512-523.

EMBRAPA (2013) Sistema brasileiro de classificação de solos. Embrapa, Rio de Janeiro, Brasil, p. 353.

Fageria NK (2009) The use of nutrients in crops plants, Boca Raton: CRC Press, Florida USA, $448 \mathrm{p}$.

Faria CM, Pereira JR, Costa ND, Cortez CR, Nakane S, Silva FA, Alves M (1999) Adubação fosfatada em tomateiro industrial em solos do Submédio São Francisco. Hortic Bras. 17: 114-117.

Garcia E, Barret M (2006) Evaluation of processing tomatoes from two consecutive growing seasons: quality atributes, peelability and yield. J Food Process Pres. 30: 37-45.

Hawkesford MW, Horst T, Kichey H, Lambers J, Schjoerring I, Skrumsager M, White P (2012) Function of macronutrients. In: Marschner P (ed). Marschner's mineral nutrition, Oxford: Elsevier Ltd, Oxford, UK. p. 135-178.

Hopkins BG, Ellsworth JW (2005) Phosphorus availability with alkaline/calcareous soil. In: Stevens WB (ed). Western nutrient management conference proceedings, Utah: Potash and Phosphate Institute, Georgia, USA. p.88-93.

IBGE (2018) Estatística mensal da produção agrícola: Levantamento sistemático da produção agrícola. $81 \mathrm{p}$.

Jiao X, Chen W, Chang AC, Page AL (2012) Environmental risk of trace elements associated with long-term phosphate fertilizers applications: a review. Environ Pollut. 168: 4452.

Liu KT, Zhang Q, Tan SC, Astatkie T (2011) Responses of fruit yield and quality of processing tomato to drip-irrigation and fertilizers phosphorus and potassium. Agron J. 103: 1339-1345.

Marques DJ, Machado-Lacerda T, Da Silva WF, Souza-Dias M, Carvalho-Biachini H (2018) Production of groups of tomatoes in substrate at different concentrations of phosphorus. J Plant Breed Crop Sci. 10: 41-47.

Melton RR, Dufault RJ (1991) Nitrogen, phosphorus and potassium fertility regimes affect tomato transplant growth. HortScience. 26: 141-142.

Mueller S, Suzuki A, Wamser AF, Valmorbida J, Feltrim AL, Becker WF (2015) Modos de aplicacao de fósforo para duas cultivares de tomate. Hortic Bras. 33: 356-361.

Nowaki RH, Parent SE, Cecílio-Filho AB, Rozane DE, Meneses NB, Silva JA, Natale W, Parent L (2017) Phosphorus overfertilization and nutrient misbalance of irrigated tomato crops in Brazil. Front Plant Sci. 8: 1-11.

Oke M, Ahn T, Schofield A, Paliyath G (2005) Effects of phosphorus fertilizer supplementation on processing quality and functional food ingredients in tomato. J Agr Food Chem. 53: 1531-1538.

Prado R (2008) Nutrição de plantas, UNESP, Jaboticabal, Brasil. p. 407. 
Raij BV, Andrade JC, Cantarella H, Quaggio JA (2001) Análise química para avaliação da fertilidade de solos tropicais, Instituto Agronômico, Campinas, Brasil. p.285.

Soares BB, Rangel R (2012) Aspectos industriais da cultura. In: Clemente FV, Boiteux $L$ (ed). Produção de tomate para processamento industrial, Embrapa, Brasília DF, Brazil. p.5.

Tóth G, Guicharnaud RA, Tóth B, Hermann T (2014) Phosphorus levels in croplands of the European Union with implications for $P$ fertilizer use. Eur J Agron. 55: 4252.

Trani PE, Raij B (1997) Hortaliças. In: Raij B et al. (ed). Recomendações de adubação e calagem para o Estado de São Paulo, Instituto Agronomico, Campinas, Brasil. p. 155203.

Trani PE, Nagai H, Passos FA (1997) Tomateiro. In: Raij VB et al. (ed). Recomendações de adubação e calagem para o Estado de São Paulo, Instituto Agronomico, Campinas, Brasil. p. 185- 186.
Wang S, Li S (2004) Effects of nitrogen and phosphorus fertilization on plant growth and nitrate accumulation in vegetables. J Plant Nutr. 27: 539-556.

Zhang TQ, Tan CS, Liu CF, Drury AP, Papadopoulos AP, Warner J (2010) Yield and economics assesments of fertilizer nitrogen and phosphorus for processing tomato with drip fertirrigation. Agron J. 102: 774-780.

Zhang XS, Liao H, Chen Q, Christie P, Li XL, Zhang FS (2007) Response of tomato on calcareous soils to different seedbed phosphorus application rates. Pedosphere. 17: 70-76.

Zhu Q, Ozores-Hampton M, Li Y, Morgan K, Liu G, Mylavarapu RS (2017) Effect of phosphorus rates on growth, yield, and postharvest quality of tomato in a calcareous soil. HortScience. 52: 1406-1412. 